\title{
Decision Support System Of Fruit Cultivation Using Technique For Other Reference Method By Similarity To Ideal Solution (TOPSIS)
}

\author{
Eva Yulianti*, Rahmat Rizki Nanda \\ Institut Teknologi Padang, Informatics Engineering Study Program, Padang, Indonesia
}

\begin{abstract}
Fruit cultivation is very promising for farmers. But there are problems faced by farmers, namely the lack of understanding of farmers with natural conditions that can affect crop yields. So with the selection of plants that are not appropriate, it does not get satisfactory results. Various types of fruit crops can be cultivated by farmers, such as oranges, guava, rambutan, watermelon, avocado, and so on. But it should be noted, that in the cultivation is expected to be cultivated plants in accordance with natural circumstances. This Designing created application to help determine the cultivation of fruit crops. In determining the cultivation of fruit crops in accordance with the criteria using the Technique Method for Others Reference by Similarity to Ideal Solution (TOPSIS) as a tool to facilitate decision-making process with several criteria of comparison, namely: temperature, sunlight, rainfall and humidity, height, harvest, selling power, susceptibility to disease, and care levels. This application is made based on the web by using PHP as a programming language and MySQL as the data storage. The use of decision support system application of the cultivation of these fruit crops can provide an output or alternative in accordance with the natural state of the area. And helps in making decisions to determine which fruits are suitable for cultivating for users based on selected criteria.
\end{abstract}

\section{Introduction}

The pattern of life by always eating fruits every day is a healthy lifestyle. This is because the fruits contain a variety of vitamins, minerals, and fiber that is needed by the body. For example, oranges. In the citrus fruit contained vitamin $\mathrm{C}$ is very good for maintaining endurance. So it is very good to be consumed every day.

Besides the purchase price of fruits that are affordable by consumers, cultivating fruits is also very promising for farmers. With proper cultivation and consideration of the natural state (temperature, sunlight, rainfall and humidity, altitude), harvesting, selling power, susceptibility to disease, and the level of care required, with appropriate action, it will most likely result in satisfying. But there are problems faced by farmers, namely the lack of understanding of farmers with natural conditions that can affect crop yields. So with the selection of plants that do not fit, then do not get optimal results.

Various types of fruit crops can be cultivated by farmers, such as oranges, guava, rambutan, watermelon, avocado, and so on. It should be noted, however, that in the cultivation it is expected that the crops will be cultivated in accordance with the natural conditions, such as temperature, sunlight, rainfall and humidity, and the altitude in West Pasaman Regency.
And also need support criteria, such as easy maintenance, long harvest, high selling power, and free from disease.

With the use of computer technology, then this can help users / farmers in choosing plants in accordance with the above-mentioned considerations contained in the area. The term system is mentioned with Decision Support System (Decision Support System), which is a system that can assist users in making decisions on what plants are suitable cultivated. How to use the system is designed as easy as possible, ie after the user to register, then the next user can log into his account. Furthermore, the user simply select the name of the fruits that can be compared by the user to get the highest or the best value by using the Technique Method For Others Reference by Similarity to Ideal Solution (TOPSIS). The results of the assessment process are recommended to users based on the highest score. So by making the right decision through the utilization of the system, it is expected that farmers will get maximum and optimal cultivation results.

TOPSIS method is one of the methods used to solve the problem of Multi Attribute Decision Making (MADM). This method is based on the concept that the best chosen alternative not only has the shortest distance from the positive solution, but also has the longest distance from the ideal solution. The TOPSIS method has advantages, including simple and easy-to- 
understand concepts, efficient computing that produces precise calculations with computers, and has the ability to measure the relative (non-fixed) performance of alternatives or multiple decision options in simple mathematical form.

\section{Methodology}

\subsection{Decision Support system}

Decision support systems are defined as a system intended to support managerial decision-makers in certain situations. Decision support systems are meant to be a tool for decision-makers to expand their capabilities, but not to replace their judgments.

Decision support system is an interactive computer-based system that helps decision makers utilize data and models to solve unstructured problems. There are several reasons for the use of Decision Support Systems, which are the unstable economic conditions, increased competition in the business world, the need for accurate new information, timely provision of information and efforts to reduce operating costs.

In addition, another reason in the development of Decision Support Systems is the change in end-user computing behavior, end-users are not programmers, so they need tools and procedures that are easy to use (Turban, 2005).

\subsection{Technique For Others Reference by Similarity to Ideal Solution (TOPSIS) Method}

The TOPSIS method is one of the methods used to solve MADM problems. The TOPSIS method is based on the concept that the best chosen alternative not only has the shortest distance from the ideal ideal solution, but also has the longest distance from the ideal solution. This concept is widely used in some MADM models to solve practical decision problems. This is because the concept is simple and easy to understand, computing efficient, and has the ability to measure the relative performance of decision alternatives in a simple mathematical form.

In general, TOPSIS procedure follows the following steps :

(1) Make a normalized decision matrix.

Topsis requires a rating on every criterion or subcriteria that is normalized. The normalized matrix is formed from the equation below :

$$
r_{i j}=\frac{r_{i j}}{\sqrt{\sum_{i}^{m}=1 x_{y}^{n}}}
$$

Description :

rij is the normalized value of each alternative (i) to criterion (j) with $\mathrm{i}=1,2, \ldots, \mathrm{m}$; and $\mathrm{j}=1,2, \ldots, \mathrm{n}$.

$\mathrm{Xij}$ is the value of an alternative (i) to criterion (j) with $\mathrm{i}=1,2, . ., \mathrm{m}$; and $\mathrm{j}=1,2, \ldots \mathrm{n}$.

(2) Calculate a weighted normalized Matrix.
After calculating the normalized value, the next step is to calculate the weighted normalization value by multiplying the value in each alternative of the normalized matrix by the weights given by the decision maker. The equations in use are :

$$
y i j=w i r i j
$$

Description :

yij is a weighted normalized value wi is the weight of each criterion

rij is the normalized value of each alternative where rij is the normalization value of each alternative (i) against criterion (j) with $i=1,2, \ldots$, $\mathrm{m}$; and $\mathrm{j}=1,2, \ldots, \mathrm{n}$.

(3) Identify positive ideal solutions and ideal negative solutions.

Positive ideal solutions and negative ideal solutions can be calculated based on the weighted normalization values as follows:

$$
\begin{aligned}
& A^{+}=\left(y 1^{+}, y 2^{+}, \ldots y n^{+}\right) ; \ldots \\
& A^{-}=\left(y 1^{-}, y 2^{-}, \ldots y n^{-}\right)
\end{aligned}
$$

Where:

$y_{j}^{-}=$

(min yij: jika ij adalah atribut keuntungan(benefit)

(max yij i jika ij adalah atribut biaya(cost)

$$
\begin{aligned}
& y_{j}^{+}= \\
& \text {(max yij : jika ij adalah atribut keuntungan(benefit) } \\
& \text { (min yij : jika ij adalah atribut biaya(cost) }
\end{aligned}
$$

$$
j=1,2, \ldots n \text {. }
$$

\section{Symbol Description:}

The positive Ideal solution $\left(\mathrm{A}^{+}\right)$is obtained by finding the maximum value of the weighted normalization value (yij) if the attribute is a gain attribute and searching for the minimum value of the weighted normalization value (yij) if the attribute is the cost attribute.

The negative Ideal solution $\left(\mathrm{A}^{-}\right)$is obtained by searching for the minimum value of the weighted normalization value (yij) if the attribute is the profit attribute and the maximum value of the weighted normalization value (yij) if the attribute is the cost attribute.

(4) Calculate the distance between the value of each alternative with the matrix of positive ideal solutions and the ideal negative solution matrix. The distance between alternative $\mathrm{Ai}$ with the ideal solution is formulated as follows: 


$$
\begin{array}{r}
D_{i}^{+}=\sqrt{\sum_{j=1}^{n}\left(y_{i}^{+}-y_{i j}\right)^{2}} \\
\ldots \ldots \ldots . .(5) \\
\mathrm{i}=1,2, \ldots, \mathrm{m} .
\end{array}
$$

The distance between alternative Ai with the ideal ideal solution is defined as:

$$
\begin{array}{r}
D_{i}^{-}=\sqrt{\sum_{j=1}^{n}\left(y_{i j}-y_{i}^{-}\right)^{2}} \\
\ldots \ldots \ldots . \\
\mathrm{i}=1,2, \ldots, \mathrm{m}
\end{array}
$$

Symbol Description:

The distance between alternatives $\mathrm{Ai}$ with the positive ideal solution $\left(\mathrm{yj}^{+}\right)$expressed in the $\mathrm{Di}^{+}$ symbol is derived from the root value of the total value of each alternative obtained with the positive ideal solution $\left(\mathrm{yi}^{+}\right)$minus the weighted normalization values for each latern (yij) then in the second.

The distance between alternatives $\mathrm{Ai}$ with the positive ideal solution ( $\left.\mathrm{yj}^{-}\right)$expressed in symbol $\left(\mathrm{Di}^{-}\right)$is derived from the root value of the sum of values of each alternative obtained with the weighted normalization value for each latern (yij) minus the positive ideal solution ( $\left.\mathrm{yi}^{-}\right)$then in the second power.

(5) Determine the value of proximity of each alternative to the ideal solution (preference).

The value of Preferences for each alternative (Vi) as follows :

$V_{\mathrm{i}}=\frac{D_{\bar{i}}^{\bar{i}}}{D_{\overline{\mathrm{i}}}^{-}+D_{\hat{i}}^{+}}$

Symbol Description:

$\mathrm{Vi}$ (The value of preference for each alternative) is obtained from the value of the ideal ideal solution distance $\left(\mathrm{Di}^{-}\right)$divided by the total value of the ideal solution solution negative (Di') plus the value of the ideal solution solution negative $\left(\mathrm{Di}^{+}\right)$.

\subsection{Context Diagram}

Context Diagram is a system design tool globally that shows the system in general and the parts of the sub system involved in the system as a whole, interconnection, and interaction between sub-systems.

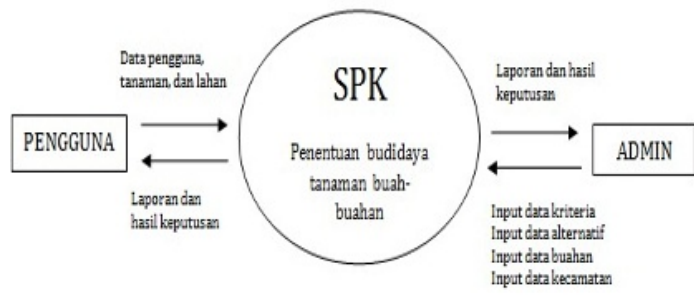

Figure 1: Context Diagram

\subsection{Entity Relationship Diagram (ERD)}

The relationship between some data in the database will be seen in the Entity Relational Diagram
(ERD). ERD is a chart that describes for the means of database design, which consists of real objects.

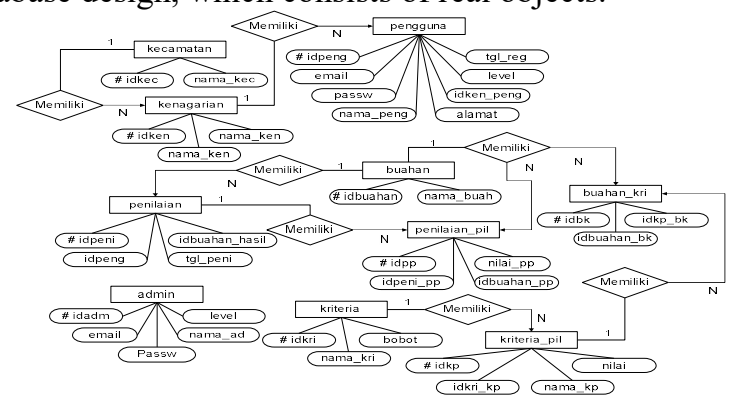

Figure 2 : Entity Relationship Diagram (ERD)

\section{Discussion}

\subsection{Home Page}

The home page is the first page that appears when users or visitors visit the website. On this page there are main menus, namely Home menu, About, List, and Login. This page view is shown in the following figure.

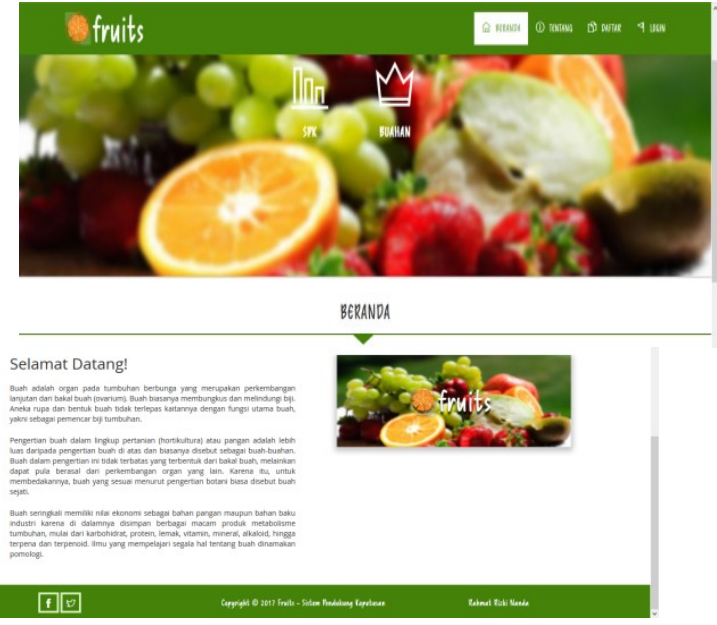

Figure 3: Home Page

\subsection{Registration Page}

The registration page is the page used by the end user to register. Thus, after successful registration then he can just make the determination of fruits in accordance with the conditions of land in the district. This page view is shown in the following figure.

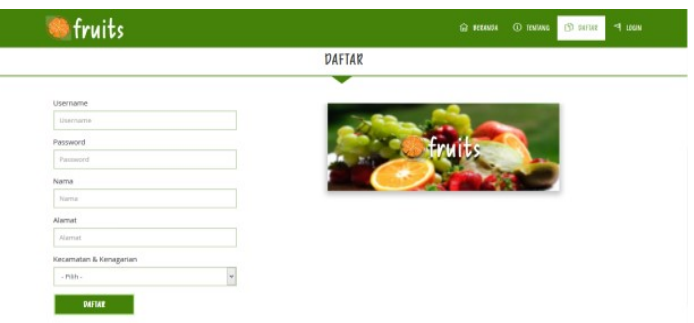

Figure 4: Registration Page

\subsection{Login Page}

The login page is the page that is used as the entrance by the end user or the application manager. 
Thus, only those who have been granted permission can enter next. This page view is shown in the following figure.

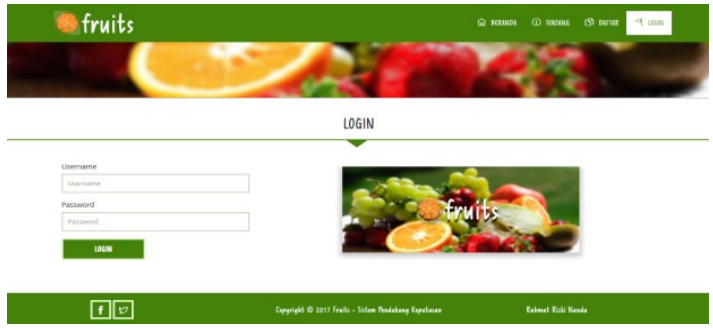

Figure 5: Login Page

\subsection{Admin Page}

The admin page is the page that displays the data of all the admin / managers who are granted permissions to manage the application. To access this page, it must be logged in as admin or operator. This page view is shown in the following figure.

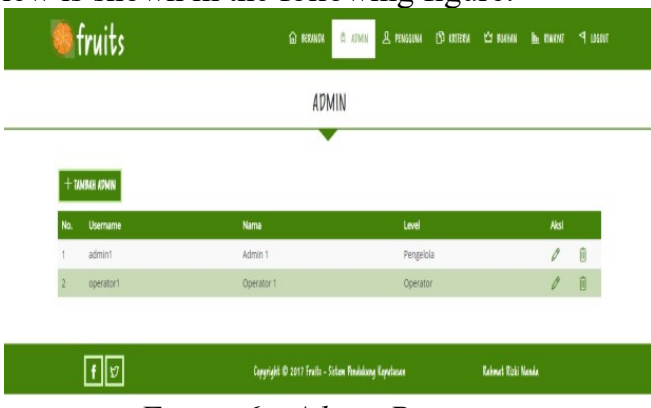

Figure 6: Admin Page

\subsection{User Pages}

The user page is the page that displays all user data that has been registered. There displayed username, name, address, and registration date. This page view is shown in the following figure.

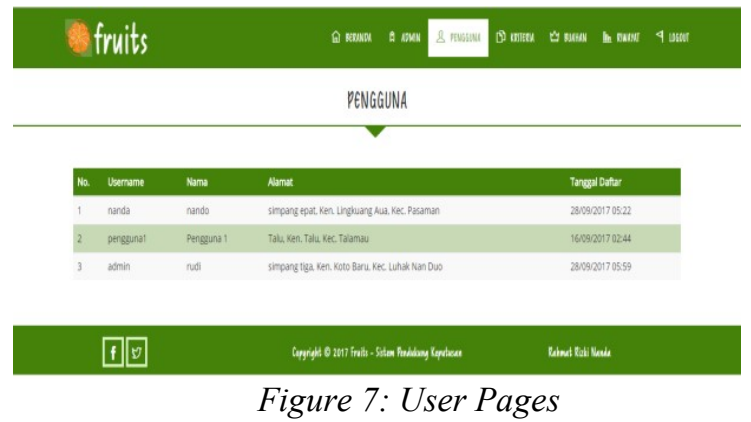

\subsection{Criteria Pages}

Criteria page is a page that displays all the data criteria that are used as assessment for fruits. The data displayed are names, weights, and options. This page view is shown in the following figure.

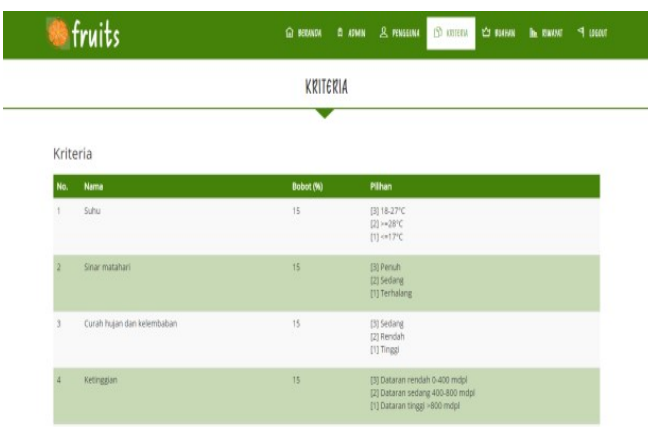

Figure 8: Criteria Pages

\subsection{Fruit Pages}

The fruits page is a page that is used to display a selection of fruits that can later be compared by the user, thus displaying the best option for the user based on the state of the land in the district. This page view is shown in the following figure.

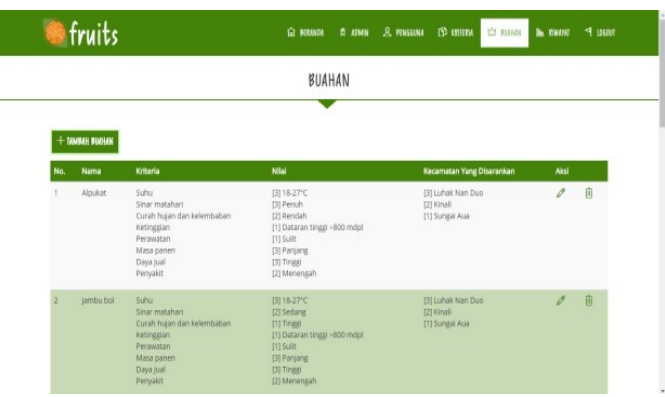

Figure 9: Fruit Pages

\subsection{Assessment Page}

An assessment page is a page that can be used by users who need advice / recommendations and as decision support in the determination of cultivation of fruit crops. Users simply choose the name of the fruits that are felt in accordance with his wishes. Then press the Process button, to start the judgment. This page view is shown in the following figure.

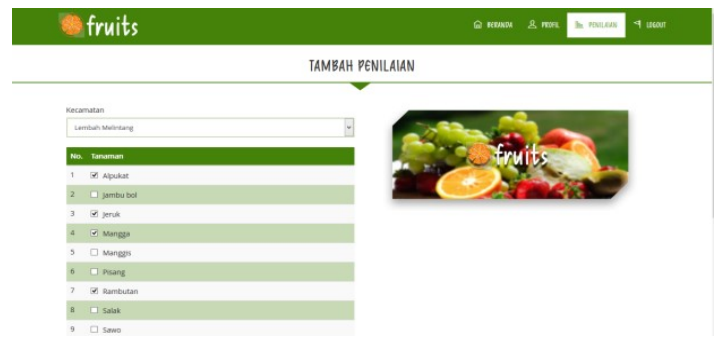

Figure 10: Assessment Page

The results of the assessment and suggestions for the best fruits are shown in the following figure. 


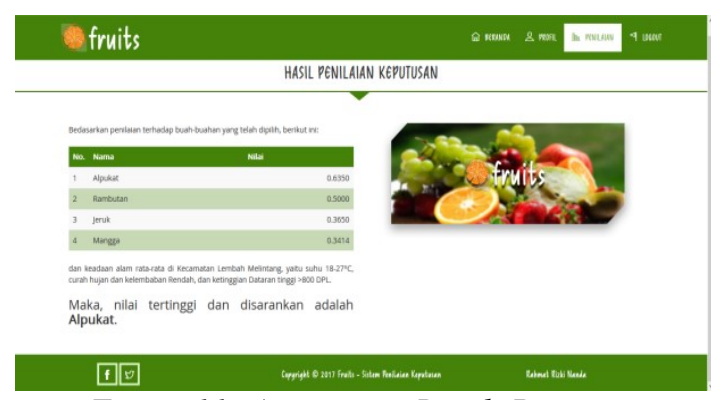

Figure 11: Assessment Result Page

\subsection{History Page}

A history page is a page that shows all the results of decision support processes or suggestions received by users based on the fruits they choose. This page view is shown in the following figure.

\begin{tabular}{|c|c|c|c|c|}
\hline \multicolumn{5}{|c|}{ RIWAYAT } \\
\hline Wo. langal & Penguna & Bastanonoth & vorantath & Dsaratan \\
\hline $1 \quad 20098201700: 65$ & Pergagal & 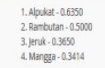 & 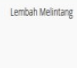 & Apuvat \\
\hline
\end{tabular}

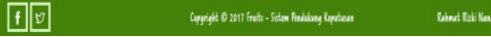

Figure 12: History Page

\subsection{Calculation of TOPSIS Method}

The following is an example of a case solved using the TOPSIS Method.

(1) A farmer in Pasaman wants to cultivate fruits that match the weather conditions in the area.

(2) Assessment

Table 1: Assessment of fruits

\begin{tabular}{|l|l|l|l|l|l|l|l|l|l|}
\hline \multirow{2}{*}{ No. } & \multirow{2}{*}{ Fruit } & \multicolumn{1}{|c|}{ Criteria } \\
\cline { 3 - 10 } & & $\mathbf{1}$ & $\mathbf{2}$ & $\mathbf{3}$ & $\mathbf{4}$ & $\mathbf{5}$ & $\mathbf{6}$ & $\mathbf{7}$ & $\mathbf{8}$ \\
\hline \hline 1 & Orange & 2 & 3 & 2 & 3 & 3 & 3 & 3 & 3 \\
\hline 2 & Banana & 3 & 2 & 3 & 1 & 3 & 3 & 3 & 1 \\
\hline 3 & Watermelon & 3 & 3 & 3 & 3 & 1 & 1 & 2 & 2 \\
\hline
\end{tabular}

Value Description :

$\begin{array}{ll}\text { Enough } & =1 \\ \text { Good } & =2 \\ \text { Very Good } & =3\end{array}$

(3) Give the weight of each criterion

Table 2: Criteria

\begin{tabular}{|c|l|c|}
\hline No. & Criteria & Weight \\
\hline \hline 1 & Temperature & $15 \%$ \\
\hline 2 & Sunlight & $15 \%$ \\
\hline 3 & Rainfall and humidity & $15 \%$ \\
\hline 4 & Height & $15 \%$ \\
\hline 5 & Care & $10 \%$ \\
\hline
\end{tabular}

\begin{tabular}{|c|l|c|}
\hline 6 & Harvest Time & $10 \%$ \\
\hline 7 & Selling Power & $10 \%$ \\
\hline 8 & Disease & $10 \%$ \\
\hline
\end{tabular}

(4) Calculating a normalized matrix Table 3 : Roots result per rank

\begin{tabular}{|c|l|c|c|c|c|c|c|c|c|}
\hline \multirow{2}{*}{ No } & \multirow{2}{*}{ Fruit } & \multicolumn{7}{|c|}{ Criteria } \\
\cline { 3 - 10 } & & $\mathbf{1}$ & $\mathbf{2}$ & $\mathbf{3}$ & $\mathbf{4}$ & $\mathbf{5}$ & $\mathbf{6}$ & $\mathbf{7}$ & $\mathbf{8}$ \\
\hline \hline 1 & Orange & 2 & 3 & 2 & 3 & 3 & 3 & 3 & 3 \\
\hline 2 & Banana & 3 & 2 & 3 & 1 & 3 & 3 & 3 & 1 \\
\hline 3 & Watermel & & & & & & & & \\
\hline & on & 3 & 3 & 3 & 3 & 1 & 1 & 2 & 2 \\
\hline $\begin{array}{l}\text { Number of rank } \\
\text { results per } \\
\text { criteria }\end{array}$ & 5 & 5 & 5 & 5 & 5 & 5 & 5 & 3 \\
\hline $\begin{array}{l}\text { Roots result per } \\
\text { rank }\end{array}$ & 7, & 8 & 8 & 5 & 5 & 5 & 8 & 2 \\
\hline
\end{tabular}

To obtain a normalized matrix, it can use the following formula. For example, to obtain a normalized matrix value for Oranges in Criterion 1 (temperature).

$$
\begin{aligned}
& r_{i j}=\frac{r_{i j}}{\sqrt{\sum_{i}^{m}=1 x_{y}^{2}}} \\
& r_{i j}=\frac{2}{\sqrt{(2)^{2}+(3)^{3+}(3)^{3}}} \\
& r_{i j}=\frac{2}{\sqrt{4+27+27}} \\
& r_{i j}=\frac{2}{\sqrt{58}} \\
& r_{i j}=\frac{2}{7,615} \\
& r_{i j}=0,26
\end{aligned}
$$

\begin{tabular}{|c|c|c|c|c|c|c|c|c|c|}
\hline \multirow{2}{*}{$\begin{array}{l}\mathbf{N} \\
\text { o. }\end{array}$} & \multirow{2}{*}{ Fruit } & \multicolumn{8}{|c|}{ Criteria } \\
\hline & & 1 & 2 & 3 & 4 & 5 & 6 & 7 & 8 \\
\hline \multicolumn{2}{|c|}{ Weight } & 15 & 15 & 15 & 15 & 10 & 10 & 10 & 10 \\
\hline 1 & $\begin{array}{l}\text { Orang } \\
\mathrm{e}\end{array}$ & $\begin{array}{l}0, \\
26\end{array}$ & $\begin{array}{l}0, \\
39\end{array}$ & $\begin{array}{c}0, \\
26\end{array}$ & $\begin{array}{l}0, \\
40\end{array}$ & $\begin{array}{l}0, \\
40\end{array}$ & $\begin{array}{l}0, \\
40\end{array}$ & $\begin{array}{l}0, \\
39\end{array}$ & $\begin{array}{l}0, \\
53\end{array}$ \\
\hline 2 & $\begin{array}{l}\text { Banan } \\
\text { a }\end{array}$ & $\begin{array}{l}0, \\
39\end{array}$ & $\begin{array}{l}0, \\
26\end{array}$ & $\begin{array}{c}0, \\
39\end{array}$ & $\begin{array}{l}0, \\
13 \\
\end{array}$ & $\begin{array}{l}0, \\
40\end{array}$ & $\begin{array}{l}0, \\
40\end{array}$ & $\begin{array}{c}0, \\
39 \\
\end{array}$ & $\begin{array}{l}0, \\
18\end{array}$ \\
\hline 3 & $\begin{array}{l}\text { Water } \\
\text { melon }\end{array}$ & $\begin{array}{c}0, \\
39\end{array}$ & $\begin{array}{c}0, \\
39\end{array}$ & $\begin{array}{c}0, \\
39\end{array}$ & $\begin{array}{l}0, \\
40\end{array}$ & $\begin{array}{l}0, \\
13\end{array}$ & $\begin{array}{l}0, \\
13\end{array}$ & $\begin{array}{l}0, \\
26\end{array}$ & $\begin{array}{c}0, \\
35\end{array}$ \\
\hline
\end{tabular}

Thus, the normalized matrix values for Oranges in Criterion 1 (temperature) were 0.26 as shown in Table 4.

Table 4 : Normalized data 
(5) Create a normalized weighted

To obtain a normalized weighted, it can use the following formula. For example, to obtain a weighted normalized value for Oranges in Criterion 1 (temperature) with a weight of $15 \%$.

$$
\begin{aligned}
& r_{i j}=w_{i} \times r_{i} \\
& r_{i j}=15 \% \times 0,26 \\
& r_{i j}=0,04
\end{aligned}
$$

Thus, the weighted normalized values for Citrus in Criterion 1 (temperature) $\mathrm{x}$ with a weight of $15 \%$ are 0.04 , as shown in Table 5.

Table 5: Normalized weighted table

\begin{tabular}{|c|l|c|c|c|c|c|c|c|c|}
\hline \multirow{2}{*}{$\begin{array}{c}\text { o } \\
\text { o. }\end{array}$} & \multirow{2}{*}{ Fruit } & \multicolumn{10}{|c|}{ Criteria } \\
\cline { 3 - 11 } & & $\mathbf{1}$ & $\mathbf{2}$ & $\mathbf{3}$ & $\mathbf{4}$ & $\mathbf{5}$ & $\mathbf{6}$ & $\mathbf{7}$ & $\mathbf{8}$ \\
\hline \hline & & 0, & 0, & 0, & 0, & 0, & 0, & 0, & 0, \\
1 & Orange & 04 & 06 & 04 & 06 & 04 & 04 & 04 & 05 \\
\hline & & 0, & 0, & 0, & 0, & 0, & 0, & 0, & 0, \\
2 & Banana & 06 & 04 & 06 & 02 & 04 & 04 & 04 & 02 \\
\hline & Water & 0, & 0, & 0, & 0, & 0, & 0, & 0, & 0, \\
3 & melon & 06 & 06 & 06 & 06 & 01 & 01 & 03 & 04 \\
\hline
\end{tabular}

(6) Looking for max and min values of normalized

\begin{tabular}{|c|c|c|c|c|c|c|c|c|c|}
\hline \multirow{2}{*}{$\begin{array}{l}\mathbf{N} \\
\mathbf{0} .\end{array}$} & \multirow{2}{*}{ Fruit } & \multicolumn{8}{|c|}{ Criteria } \\
\hline & & 1 & 2 & 3 & 4 & 5 & 6 & 7 & 8 \\
\hline 1 & Orange & $\begin{array}{l}0, \\
04\end{array}$ & $\begin{array}{l}0, \\
06\end{array}$ & $\begin{array}{l}0, \\
04\end{array}$ & $\begin{array}{l}0, \\
06 \\
\end{array}$ & $\begin{array}{l}0, \\
04\end{array}$ & $\begin{array}{l}0, \\
04\end{array}$ & $\begin{array}{l}0, \\
04\end{array}$ & $\begin{array}{l}0, \\
05\end{array}$ \\
\hline 2 & Banana & $\begin{array}{c}0, \\
06\end{array}$ & $\begin{array}{c}0, \\
04\end{array}$ & $\begin{array}{c}0, \\
06\end{array}$ & $\begin{array}{l}0, \\
02\end{array}$ & $\begin{array}{c}0, \\
04\end{array}$ & $\begin{array}{c}0, \\
04\end{array}$ & $\begin{array}{c}0, \\
04\end{array}$ & $\begin{array}{l}0, \\
02\end{array}$ \\
\hline 3 & $\begin{array}{l}\text { Water } \\
\text { melon }\end{array}$ & $\begin{array}{l}0, \\
06 \\
\end{array}$ & $\begin{array}{l}0, \\
06 \\
\end{array}$ & $\begin{array}{l}0, \\
06 \\
\end{array}$ & $\begin{array}{l}0, \\
06 \\
\end{array}$ & $\begin{array}{l}0, \\
01 \\
\end{array}$ & $\begin{array}{l}0, \\
01 \\
\end{array}$ & $\begin{array}{l}0, \\
03 \\
\end{array}$ & $\begin{array}{l}0, \\
04 \\
\end{array}$ \\
\hline \multicolumn{2}{|c|}{ Max } & $\begin{array}{l}0, \\
06\end{array}$ & $\begin{array}{l}0, \\
06 \\
\end{array}$ & $\begin{array}{l}0, \\
06 \\
\end{array}$ & $\begin{array}{l}0, \\
06 \\
\end{array}$ & $\begin{array}{l}0, \\
04 \\
\end{array}$ & $\begin{array}{l}0, \\
04 \\
\end{array}$ & $\begin{array}{l}0, \\
04 \\
\end{array}$ & $\begin{array}{l}0, \\
05 \\
\end{array}$ \\
\hline \multicolumn{2}{|c|}{ Min } & $\begin{array}{c}0, \\
04\end{array}$ & $\begin{array}{c}0, \\
04\end{array}$ & $\begin{array}{c}0, \\
04\end{array}$ & $\begin{array}{l}0, \\
02\end{array}$ & $\begin{array}{l}0, \\
01\end{array}$ & $\begin{array}{l}0, \\
01\end{array}$ & $\begin{array}{c}0, \\
03\end{array}$ & $\begin{array}{l}0, \\
02\end{array}$ \\
\hline
\end{tabular}
weights

Table 6: Max and min values

(7) Search for $\mathrm{D}^{+}$and $\mathrm{D}^{-}$any alternatives

To obtain a positive ideal solution, then can use the following formula. For example, to get the value of Orange in Criterion 1 (temperature).

$$
\begin{gathered}
D_{i}^{+}=\sqrt{\sum_{j=1}^{n}\left(y_{i}^{+}-y_{i j}\right)^{2}} \\
D_{i}^{+}=\sqrt{\begin{array}{l}
(0,04-0,06)^{2}+(0,06-0,06)^{2}+(0,04-0,06)^{2}+(0,06-0,06)^{2}+ \\
(0,04-0,04)^{2}+(0,04-0,04)^{2}+(0,04-0,04)^{2}+(0,05-0,05)^{2}
\end{array}} \\
D_{i}^{+}=\sqrt{0,000775862} \\
D_{i}^{+}=0,027854301
\end{gathered}
$$

Thus, the value of a positive ideal solution for Oranges in Criterion 1 (temperature) was 0.077032 , as seen in Table 7.

Table 7: $D^{+}$Value

\begin{tabular}{|l|l|c|c|c|c|c|c|c|c|}
\hline \multirow{2}{*}{$\begin{array}{l}\text { o } \\
\text { F }\end{array}$} & \multirow{2}{*}{$\begin{array}{l}\text { Fru } \\
\text { it }\end{array}$} & \multicolumn{10}{|c|}{ Criteria } \\
\cline { 3 - 9 } & & $\mathbf{1}$ & $\mathbf{2}$ & $\mathbf{3}$ & $\mathbf{4}$ & $\mathbf{5}$ & $\mathbf{6}$ & $\mathbf{7}$ & $\mathbf{8}$ \\
\hline \hline 1 & Ora & 0,0 & 0 & 0,0 & 0 & 0 & 0 & 0 & 0 \\
& nge & 00 & & 00 & & & & & \\
& & 38 & & 38 & & & & & \\
& & 8 & & 8 & & & & & \\
\hline 2 & Ban & 0 & 0,0 & 0 & 0,0 & 0 & 0 & 0 & 0,0 \\
& ana & & 00 & & 01 & & & & 01 \\
& & & 38 & & 63 & & & & 25 \\
& & & 8 & & 6 & & & & \\
\hline 3 & Wat & 0 & 0 & 0 & 0 & 0,0 & 0,0 & 0,0 & 0,0 \\
& erm & & & & & 00 & 00 & 00 & 00 \\
& elo & & & & & 72 & 72 & 17 & 31 \\
& n & & & & & 7 & 7 & 2 & 3 \\
\hline
\end{tabular}

Table $8: D^{-}$Value

\begin{tabular}{|l|l|c|c|c|c|c|c|c|c|}
\hline N & \multirow{2}{*}{$\begin{array}{l}\text { Fru } \\
\text { it }\end{array}$} & \multicolumn{8}{|c|}{ Criteria } \\
\cline { 3 - 9 } & $\mathbf{1}$ & $\mathbf{2}$ & $\mathbf{3}$ & $\mathbf{4}$ & $\mathbf{5}$ & $\mathbf{6}$ & $\mathbf{7}$ & $\mathbf{8}$ \\
\hline \hline & & 0 & 0,0 & 0 & 0,0 & 0,0 & 0,0 & 0,0 & 0,0 \\
& & & 00 & & 01 & 00 & 00 & 00 & 01 \\
& Ora & & 38 & & 63 & 72 & 72 & 17 & 25 \\
1 & nge & & 8 & & 6 & 7 & 7 & 2 & \\
\hline & & 0,0 & 0 & 0,0 & 0 & 0,0 & 0,0 & 0,0 & 0 \\
& & 00 & & 00 & & 00 & 00 & 00 & \\
& Ban & 38 & & 38 & & 72 & 72 & 17 & \\
2 & ana & 8 & & 8 & & 7 & 7 & 2 & \\
\hline & Wat & 0,0 & 0,0 & 0,0 & 0,0 & 0 & 0 & 0 & 0,0 \\
& erm & 00 & 00 & 00 & 01 & & & & 00 \\
& elo & 38 & 38 & 38 & 63 & & & & 31 \\
3 & n & 8 & 8 & 8 & 6 & & & & 3 \\
\hline
\end{tabular}

Table $9: D^{+}$and $D^{-}$values of each alternatif

\begin{tabular}{|c|l|r|r|}
\hline No. & Fruit & D $^{+}$ & D $^{-}$ \\
\hline \hline 1 & Orange & 0,027854 & 0,070009 \\
\hline 2 & Banana & 0,057221 & 0,049019 \\
\hline 3 & Watermelon & 0,044039 & 0,055791 \\
\hline
\end{tabular}

(8) Search for V/ results

To get a preference value, then can use the following formula. For example, to get the value of Orange

$$
\begin{aligned}
V_{i} & =\frac{D_{i}^{-}}{D_{i}^{-}+D_{i}^{+}} \\
V_{i} & =\frac{0,070008956}{0,070008956+0,027854301} \\
V_{i} & =0,715375293
\end{aligned}
$$

Thus, the preference value for Orange is 0.715375293 , as in Table 10.

Table 10 : Final Result 


\begin{tabular}{|l|l|l|}
\hline \multicolumn{1}{|c|}{ No. } & \multicolumn{1}{|c|}{ Fruit } & Vx \\
\hline \hline 1 & Orange & 0,715375 \\
\hline 2 & Banana & 0,461395 \\
\hline 3 & Watermelon & 0,558859 \\
\hline
\end{tabular}

From the value of $\mathrm{Vx}$ above, the highest value is 0.715375 . Thus, it can be concluded that a very good alternative cultivated based on the available criteria are Orange fruits.

\section{Conclusions and Recommendations}

Based on the discussion done in this research, it can be concluded that Decision Support System Determination of Plant Cultivation Fruits can facilitate the farmers take decisions and can be useful for the general public as well. By building this application can support farmers in the determination of the cultivation of fruit crops with several criteria as a guide assessment in the determination of fruit crop cultivation.

The recomendation that can be submitted by writer to the next research is to develop this application with other method, such as linear regression method, B / C ratio, IRR and others. In order to compare the results which are more efficient and accurate.

\section{References}

[1] Arsyad, S.(1989). Konservasi Tanah dan Air. Bogor : Institut Pertanian Bogor.

[2] Aronoff, S.(1989). Geografhic Information System : Management Perspective. Canada : WDL publication Ottawa.

[3] Habibullah, A., \& Winiarti, S. (2014). Sistem Pendukung Keputusan Penentuan Kesesuain Jenis Lahan Pertanian Untuk Budidaya Tanaman Buah-Buahan Menggunakan Metode Similarity Berbasis Web. JSTIE (Jurnal Sarjana Teknik Informatika)(E-Journal), 2(2), 336-344.

[4] Hasan. (2004). Pokok-Pokok Materi Teori Pengambilan Keputusan. Jakarta : Ghalia Indonesia.

[5] Kusrini. (2007). Konsep dan Aplikasi Sistem Pendukung Keputusan. Yogyakarta: Andi Offset.

[6] Kusumadewi, Sri. (2006). Fuzzy MultiAttribute Decision Making (Fuzzy MADM). Yogyakarta: Graha Ilmu.

[7] Sulistyawati, T. (2015). Sistem Pendukung Keputusan Untuk Penentuan Penerima Beasiswa Di Universitas Muhammadiyah Surakarta Berbasis Web Dengan Metode Topsis (Doctoral dissertation, Universitas Muhammadiyah Surakarta).
[8] Turban, Efraim. (2005). Decision Support Systems and Intelligent Systems (Sistem Pendukung Keputusan dan Sistem Cerdas) Edisi 7 Jilid 1. Yogyakarta: Penerbit Andi 